\title{
RELATIVE POVERTY IN TURKEY BETWEEN 1994 AND 2006
}

\author{
Tuncay Guloglu ${ }^{1}$, Kemal Aydin ${ }^{2}$, Fatma Kahraman Guloglu ${ }^{3}$ \\ ${ }^{1}$ Yalova University, Turkey, tguloglu96@yahoo.com \\ ${ }^{2}$ Istanbul Medeniyet University, Turkey, kaydin709@gmail.com \\ ${ }^{3}$ Yalova University, Turkey, ftmkahraman@gmail.com \\ cross'ref http://dx.doi.org/10.5755/j01.em.17.1.2264
}

\begin{abstract}
This article examines relative poverty in Turkey in terms of changes and varying dimensions. It is based on annual and monthly disposable income criteria during the period spanning 1994-2006. In the first part of this study, we discussed conceptualization, measurement and differing approaches to poverty. This examination includes both global and regional definitions for poverty levels each varying in measure. Building on this discussion, we explored poverty in modern day Turkey and presented several research findings concerning the rate and dimensions of poverty in Turkey. In the second section of this article, the rates and varying dimensions of relative poverty cases in Turkey were analyzed. To accomplish this, five nationally cross-sectional representative household surveys named as "Household Budged and Income Distribution Survey" of 1994, 2003, 2004, 2005 and 2006 were utilized.

Keywords: Relative poverty, income distribution, socio-economic indicators.

JEL Classification: D33, I38, R20.
\end{abstract}

\section{Introduction}

Poverty and income inequality are drastic socio-economic problems in the world. Poverty and inequality are also complex, heterogeneous phenomena. From country to country, there are varied poverties and income inequalities. Poverty has been an important problem in Turkey with the new millennium and it is seen as one of the most important social problems. This paper analyzed changes and varying dimensions of relative poverty in Turkey based on annual and monthly disposable income criteria during the period spanning 1994-2006.

This paper focused on relative poverty in Turkey. In the first part of this study, we discussed conceptualization, measurement and differing approaches to poverty. This examination includes both global and regional definitions for poverty levels each varying in measure. Building on this discussion, we explored poverty in modern day Turkey and presented several research findings concerning the rate and dimensions of poverty in Turkey. In the second section of this article, the rates and varying dimensions of relative poverty cases in Turkey were analyzed. To accomplish this, five nationally cross-sectional representative household surveys named as "Household Budged and Income Distribution Survey" of 1994, 2003, 2004, 2005 and 2006 were utilized.

\section{Poverty: Conceptualization and Measurement}

Poverty, a complex, multidimensional, and universal socio-economic problem, has in recent years become a widely debated issue among the policy makers of all levels of government and researchers. Poverty is not a new issue, it has always existed in human societies and periodically its significance has increased in priority on policy makers' agendas. However, sometimes poverty becomes a more pressing social problem and receives more attention. In this respect, it maybe useful to compare our contemporary times with mideighteenth century setting when Adam Smith, considered the founder of economics, wrote his book "The Theory of Moral Sentiments." In this book, Adam Smith approached poverty as something which renders the poor person invisible to other people and hence makes him or her socially nonexistent (Bugra \& Keyder, 2005).

As we saw earlier, poverty is very often considered the fault of the poor themselves. In some countries, people blame the poor for lack of economics success. However, poverty is an economic state. People are poor because they lack money. Moreover, they lack money because they are unable to sell their labor, or because they are paid only very small incomes. In other words, the cause of poverty is not the poor but is instead the nature of political and economic systems (Neubeck \& Neubeck, 1997).

In the contemporary world, there are many reasons of poverty. Some of them are explained below.

1. Technological Change: Decisions by executives in business and in industry to automate or increase mechanization of their operations in order to increase efficiency and profits have resulted in displacement of many workers and have closed opportunities for new entrants into the labor force. Those most affected by technological change are unskilled and semi skilled workers. 
2. The Policy of Employers: Employers contribute to the creation and perpetuation of poverty in other ways as well. For example, many of our largest corporations have become international operations with plants around the world. On the other hand, low wage policy of employers is on e of the important reasons for working poor.

3. Elderly Population: As we have seen, age is closely linked to poverty. Many adults reach retirement age only to find that their savings and other economic resources are inadequate. For most of this century, the elderly were much more likely than other people to be poor. Income is a crucial determinant of how the aged live. The level, the adequacy and the maintenance of income affects other aspects of the lives of the elderly. Elderly people depend on different income sources such as real estate, private and public pension and interest from their saving. For this reason, the economic structure, payments, taxes and the inflation rate influence the income of elderly people and sometimes push them into poverty. Saving is the most important factor for poverty in old age. In general, during their work life, people have to save money for their old age, but some people do not have enough of a chance to save because of low wages, children and the high cost of living ( Neubeck \& Neubeck, 1997; Guloglu \& Yumusak, 2008).

4. Sex and Marital Status: Sex and marital status are also linked to the probability that one will be poor and will find it difficult to extricate oneself from poverty. We are seeing the slow feminization of poverty as more women with young children are affected.

5. Government Policies: Government policies can obviously affect the degree to which poverty and unemployment persist and lead to suffering. Welfare measures, job-training programs, unemployment insurance, aid to families with dependent children, and like alleviate the shock of unemployment, and job training programs give new hope( Glynn et al., 1996)

Poverty is first and foremost an economic state. Being poor means, essentially, lacking a means of subsistence capable of providing what -in this society and at this time - could be considered a secure and adequate standard of living. On the other hand, poverty is an absolute state: By any objective measure, the poor are materially deprived to the point where survival often becomes an issue. And, on the other hand, poverty is a relative state: The poor are materially deprived in comparison with the majority of the population (Neubeck\& Neubeck, 1997 )

Poverty can be understood in both absolute and relative poverty terms. Absolute poverty is based on a fixed level of resources, or threshold. If a person's resources fall below the threshold, he or she is viewed as experiencing "absolute" poverty. Relative poverty is based on comparison. If an individual's situation is disadvantaged compared to someone else's, or compared to what it was in the past, he or she is viewed as experiencing relative poverty (Barusch, 2002).

Although it has been intensely debated, no commonly agreed-upon definition of poverty has emerged. Overall, the two most commonly accepted definitions for poverty, utilized by researchers are 'absolute poverty' and 'relative poverty'. While World Bank defines and measures in terms of absolute poverty, other researchers commonly define and measure poverty as a relative concept. Absolute poverty line is defined to be equal to $\$ 1, \$ 2.15$ and $\$ 4.30$ per day (Saunders, 1998). However, absolute poverty line on $\$ 1$ per day utilized by World Bank is criticized by researchers who argue that national poverty line is better criteria.

The most common definition of poverty used in the United States, the Federal Poverty Threshold, is an absolute measure, it is used by the Census Bureau to gauge the level of poverty in the nation, and serves as the basis for official allocation of several means-tested programs, including the Food Stamp Program (Barusch, 2002).

Mallie Orshansky developed the Federal Poverty Threshold of the US in the 1960s. The poverty threshold has been changed in two ways. In 1969, the measure was indexed to the Consumer Price Index (CPI). Then in 1981, in response to political pressure and technical arguments, the thresholds for farm families and female-headed households were raised to the standard level. The threshold for those older than 65 remains 8 to 10 percent below that of older households (Barusch, 2002).

Some people have argued that the federal poverty threshold overestimates the extent of poverty in the United States because it does not count in-kind benefits such as food stamps, housing assistance, and medical programs as income as income. According to this view, the in kind benefits such as food stamps, housing assistance and medical programs should be considered as income. Others argue that the federal poverty threshold underestimates financial hardship. Mollie Orshansky, the economist who developed the poverty threshold, suggested that it was at least 40 percent too low because the multiplier used to estimate total costs as three times the food costs was too small. Another problem with the federal poverty threshold is its failure to take into account regional differences in the cost of living (Barusch, 2002). 
Poverty is also commonly measured based on the lack of necessities such as food, clean water and shelter. This consideration begets a consideration of relative poverty. The term is generally considered to indicate a lack of equal opportunities in terms of income, access to education, and occupation. It is necessary to note that as the standard of living increases, the level of relative poverty increases as well. Thus, the concept of relative poverty is closely tied to the fluctuating economic conditions of the nation in which it is being measured.

On the other hand, Peter Townsend argued that the relative poverty income standard of poverty is arbitrary: it is unclear why the poverty line should be drawn at 50 per cent of average income- 70 per cent could have jus as much validity. Townsend was therefore keen to establish a more objective and less arbitrary measure of poverty and need, but one which was necessarily relative to wider standards in society. Townsend argued, therefore that poverty had to be related to more than simply material impoverishment. With this in mind, he focused upon the concept of relative deprivation. He suggested that any definition of poverty should include some measure of an individual's ability to participate in social activities which are generally customary in society ( Liddiard, 2007).

In 19990s more refined conceptualization and measurements has formulated by the United Nations Development Program (UNDP) which developed a concept called 'human development' based on the ideas of Sen $(1992,1999)$. The UNDP since 1990s has published annual reports ranking countries in regards to their level of human development. The Human Development Index (HDI) investigates certain factors that the UNDP relates to human development, including income, life expectancy at birth, literacy and school enrollment rates. A country that receives a low HDI rating implies that those who live in poverty experience deprivation in regards to capability since it implies a limited fulfilment of basic needs. According to the results of UNDP's findings, no direct link exists between national per capita income and indicators of human development (Bugra \& Keyder; 2005). For instance, Turkey has not achieved the level of human development that would be expected given her ranking as 70th in regards to per capita income. Turkey's position on the human development continuum; however, show that Turkey is among the fastest progressing countries. In 1965, Turkey was among the lower-ranked in the human development category, scoring 0.438 out of maximum score of 1 . In 1972, Turkey had moved to the medium category ranking $85^{\text {th }}$ out of 174 countries, however, in 2002, Turkey dropped into 96th place in 2003 due to the effect of financial crises and ranked 84th out of 177 countries in 2008. According to the latest relief, Turkey in 2011 ranked as 92 out of 187 countries (UNDP, 2011; UNDP, 2009).

\section{Dimension of Poverty in Turkey}

Poverty has been an important problem in Turkey with the new millennium and is seen as one of the most important social problems. The economic crises in the early previous decade and two big earthquakes have been two factors in the issue being on Turkey's agenda. During this period, the related institutions, politicians and researchers have been more active in defining the borders of poverty and determining the poverty line (Guloglu \& Aydin, 2011).

At the end of 1990s, the effects associated with poverty had gained such importance that it was an important issue policy makers in Turkey. After Turkey gained the candidate status to membership to the European Union, poverty and inequality problems have become more considerable. According to the Statistical Office of European Communities (Eurostat) in 2006 Turkey's gini coefficient of 0.44,8 stands well above those for old and new member states and candidate countries. Turkey faces, in other words, a very serious task for the eradication of poverty and inequality on its way to EU accession (Guloglu \&Guder, 2007).

On the other hand, research carried out in Turkey has tied poverty to several reasons:

1. Income Distribution Inequality: Turkey's gini coefficient has decreased from 0.49 in 1994 to $0.44,8$ in 2006 but the rate is still higher than the EU average. Although the problem is not as bad as it used to be, Turkey still has an income distribution problem. While the bottom 20 percent of the population gets 6 percent of the income, the top 20 percent of the population gets 46.2 percent of the income (TUIK, 2004).

2. Low wages: The average before tax monthly wage in 2006 has been 1,099 TL in Turkey but real wages have been declining with the economic crisis.

3. Inter-Regional Discrepancies: There have been historical income discrepancies in Turkey due to geography, the distribution of qualified labor, proximity to markets and trade paths, climate and capital accumulation. The Aegean region is the area with the lowest poverty rate and the East Anatolian Region with the highest (Es \& Guloglu, 2004). 
4. Informal Employment: There is a close link in Turkey between informal employment and poverty. The non-skilled labor that migrated to the urban areas works in informal employment and this type of work is disorderly and the pay is inadequate (Es \& Güloğlu, 2004).

5. Migration to Urban Areas: There is a rapid migration from rural to urban areas because of modern technologies being used in agriculture, lower productivity, the fragmentation of agricultural lands due to inheritance and other socio-economic reasons. The Marmara Region and cities in the Aegean, Mediterranean and Western Anatolian Regions attract migration due to employment opportunities in industry and services (TUIK, 2000).

Similarly, researchers also began to view the consequences of poverty as crucial to properly understanding socio-economic profiles. Specifically, in 2001, Turkey was strongly impacted by the most severe financial crisis in the country's history. In addition to the heaviest financial crisis, two earthquakes of intense magnitude shake the country. As in other developing nations, unstable and inconsistent economic development, the shrinkage of agricultural production, rapid migration, and weakening of long-standing traditional family ties have all contributed to the increasing prevalence of poverty in Turkey. (Dikmen, 2002; Bugra \& Keyder 2003; Senses, 2002; Erdogan, 2003; Bugra \& Sinmazdemir 2005; Oktik, 2008; Bugra, 2008). As a result, in 2002 the Turkish Statistical Institution (TSI) conducted the survey, with sample size of 9600 households, to set the poverty line and measure various dimensions of poverty in Turkey. According to the criteria set forth by TSI, monthly food poverty line for 2002 for an individual was defined to be 73 million TL (\$96) US dollars; and monthly food plus non-food poverty line for single person was defined to be 171 million TL (\$234). Individuals who earned less than 171 million were categorized as 'poor'. For a 4-person family, the food poverty line was set as 167 million TL (\$220) and 387 million TL (\$511) for food plus non-food. According to TSI's definition, $1.35 \%$ of the sample was found to be below the food poverty line. The rates were $0.92 \%$ in urban and $2.01 \%$ in rural households. Of the households surveyed $27 \%$ were found to be below both the food and the non-food poverty line. In urban areas, $21 \%$ of the samples were found to be below the poverty line, while the rate in rural areas was $34 \%$. In addition, proportion of the population living below power purchasing parity (ppp) $1 \$, 2,15 \$$ and $4,30 \$$ dollars criteria per day, in Turkey, $0.20 \%$ were fell below $\$ 1$ dollar, 3\% below $\$ 2.15$ and $30 \%$ below $\$ 4,30$ US dollars per day. The overall relative poverty rate was $15 \%$. In urban center, the rate was $11 \%$ and in rural areas, it was found to be $20 \%$ (DIE, 2004).

The second study of major importance was conducted by the World Bank with sample size composed of 4200 households. The World Bank (2003) reported that the percentage samples living below the absolute poverty line (\$1 US per person per day) was less than 2 percent in 2000. This was the case in 1994 as well. The urban food and non-food poverty rates were $17 \%$ and $56 \%$ respectively. Relative poverty rate according to Ozcan's findings in the same report, were $22 \%$. Furthermore, according to the World Bank's comparison with the household income and expenditure survey (HCIS) of 1994, for the country as a whole (urban and rural) 7.3 percent of the population found to be below food poverty based on equivalent expenditures on the estimation of the food basket. The rate of the food poverty was 6 percent in urban area. However, according to the World Bank's comparison between 1994 and 2001, 17 percent of the urban population had per equivalent expenditures below the imputed value of a food basket. Furthermore, World Bank reporters suggested that the combined effects of the earthquake and financial crisis caused the level of urban poverty to increase in 2001. To summarize these reports mentioned above and others, all indicated that the rate of food poverty varied from a minimum of $1.3 \%$ to a maximum of $10 \%$. The range of measurements food plus non-food poverty rates varied between $26 \%$ and $36 \%$, depending on the sample size and years measured (Dumanl1, 1996; Erdogan, 1998; Dagdemir, 1987; Gursel, 2000; World Bank, 2000a, 2000b; Yemtsov, 2001; Yardimci at all, 2003).

\section{Data and Methodology}

The analysis in this study is based on pooled data from five years of the "Household Budget and Income Distribution Survey" nationally representative cross-sectional surveys conducted by the TSI in 1994, 2003, 2004, 2005, 2006. The TSI carried out household survey every decade with a large sample size until 2003. After 2003, it was conducted every year with a smaller sample size. The sample sizes included in this study are the following: 26,126 households for 1994, 25,764 households for 2003; 8,544 households for 2004; 8556 households for 2005; and 8556 households for 2006. In other words, the total sample size used in this analysis was 77,546 households, in all seven geographical regions consisting of both urban and rural settlements in Turkey for a period of duration spanning 1994 to 2006. There were some differences in variables. For example, household size and employment status were not included in 1994 data for the 
analysis. In 2006 data, age of respondents did not included due to different age coding by TSI. The stratified multi-stage systematic cluster sampling method was used in all four surveys. In settlements where the population was at least 20,001 residents was defined as urban and those settlements with fewer than 20,000 citizens were defined as rural (DIE, 1994; Turkish Statistical Institute, 2003; 2004; 2005; 2006).

The unit of analysis in this paper with regards to income is the head of household's disposable annual and monthly income respectively. Head of the household is the one who is responsible for the income and expenditures of the household. The head of household's monthly and annual disposable income (income in cash and income of all types for the head of household was used for determining the income annually and monthly), was used in comparing the relative poverty rate between 1994, 2003, 2004, 2005 and 2006. Calculation and comparison of relative poverty in the years from 2003 to 2006 is based on household heads' monthly disposable income. $10 \%$ of the samples were female, $36 \%$ was rural and $64 \%$ of them urban. $12 \%$ of the samples were below elementary or no schooling, $50 \%$ of the samples were primary school. For occupational classification, TSI used International Standard Classification of Occupation

The poverty line used in this paper is based on the definition set by OECD. It also takes into consideration how the European Union defines relative poverty and economic distance, which is defined to be $50 \%$ of the median income level for heads of household for and annual and monthly disposable income and expenditures. In other words, those who fall below $50 \%$ of the median annual and monthly disposable income and expenditures per household are defined as relatively poor or poor according to OECD scale. Applying the absolute poverty definitions of $\$ 1$ and $\$ 2.15$ income per day in the case of Turkey did not produce statistically significant results and therefore they were excluded in this analysis (World Bank, 2003). Secondly, the incidence of relative poverty is a particularly important issue in Turkey due to a significantly unequal income distribution, informal sectors, undeclared work and the shadow economy (Yereli at all., 2006).

The first part of the analysis compares and decomposes trends in the relative poverty rate between 1994 and 2006 in terms of household heads' annual income among the rural vs. urban, gender, age, educational attainment, occupation and regional occupation. Within the second part of the analysis, the same socio-economic and demographic variables were compared among the household heads in terms of their monthly disposable income between 2003 and 2006 data sets. Finally, to summarize the results, multivariate logistic regressions were run to measure the relative impact of the socio-economic and demographic variables to predict which variables would be significant indicators of relative poverty.

\section{Results}

The analysis decomposes income and relative poverty in terms of the following: Rural-urban occupancy, gender, age, household size, educational degree, occupational and employment status. Tables 1 through 7 decompose relative poverty in terms of socio-economic and demographic characteristics in response to annual income and table 8 to 14 decompose the same variables in response to monthly income.

Both portions utilize the mark of below 50\% of the median income level for the heads of the households as the defining line for determining the level of income which for all who fall below are considered to fall into the category for relative poverty.

Table 1. Annual income and rural-urban relative poverty rate

\begin{tabular}{|c|c|c|c|}
\hline Years & Rural & Urban & Total \\
\hline 1994 & $24 \%$ & $15 \%$ & $18 \%$ \\
\hline 2003 & $19 \%$ & $12 \%$ & $14 \%$ \\
\hline 2004 & $24 \%$ & $11 \%$ & $15 \%$ \\
\hline 2005 & $22 \%$ & $12 \%$ & $15 \%$ \\
\hline 2006 & $23 \%$ & $10 \%$ & $14 \%$ \\
\hline
\end{tabular}

First of all, 1994 and 2003 data were almost same in terms of sample size and structure of the surveys. Between 2004 and 2006, each sample size was varied about eight thousands but sample size of 1994 and 2003 was 25,000 each and therefore 1994, 2003, and 2004 to 2006 should be interpreted separately. The cross tabs indicate that relative poverty decreased from $24 \%$ to $19 \%$ in rural and $15 \%$ to $12 \%$ in urban location between 1994 and 2003. There was 4\% decline over nine-year period. Overall, between 2004 and 2006 the rates for relative poverty for both urban and rural occupancy remained almost constant; thus there was no significant change in relative poverty rates for either rural or urban locations between the beginning and the end of the period surveyed. 
Table 2. Annual income, gender and relative poverty

\begin{tabular}{|c|c|c|c|}
\hline Years & Male & Female & Total \\
\hline 1994 & $16 \%$ & $33 \%$ & $18 \%$ \\
\hline 2003 & $12 \%$ & $34 \%$ & $14 \%$ \\
\hline 2004 & $13 \%$ & $33 \%$ & $15 \%$ \\
\hline 2005 & $13 \%$ & $34 \%$ & $15 \%$ \\
\hline 2006 & $12 \%$ & $36 \%$ & $14 \%$ \\
\hline
\end{tabular}

Table 2 displays the comparison of relative poverty rates for households headed by female and male. In 1994, percentage of relative poverty among male households was $16 \%$ on average while it was $33 \%$ among female household heads. The poor ratios in 2003 between them were $12 \%$ to $34 \%$ respectively. Between 2004 and 2006, the percentage of male households who were considered relatively poor was consistently centered at $12 \%$. On the other hand, approximately $33 \%$ of female-headed households were considered relatively poor. These two figures denote a stark contrast of $20 \%$ in variance between the two classes of households.

Table 3. Annual income, age and relative poverty rates

\begin{tabular}{|c|c|c|c|c|c|c|}
\hline Age & 29\&below & $\mathbf{3 0 - 3 9}$ & $\mathbf{4 0 - 4 9}$ & $\mathbf{5 0 - 5 9}$ & 60\&over & Total \\
\hline 1994 & $24 \%$ & $14 \%$ & $10 \%$ & $14 \%$ & $29 \%$ & $17 \%$ \\
\hline 2003 & $17 \%$ & $13 \%$ & $12 \%$ & $12 \%$ & $21 \%$ & $14 \%$ \\
\hline 2004 & $17 \%$ & $12 \%$ & $13 \%$ & $14 \%$ & $22 \%$ & $15 \%$ \\
\hline 2005 & $13 \%$ & $13 \%$ & $12 \%$ & $14 \%$ & $22 \%$ & $14 \%$ \\
\hline
\end{tabular}

The results in Table 3 indicate that the incidence of relative poverty was relatively higher among household heads below the age of 30 and above the age of 60s.

Table 4. Annual income, household size and relative poverty

\begin{tabular}{|c|c|c|c|c|c|}
\hline Years & $\mathbf{1}$ to 3 & $\mathbf{4}$ to 6 & $\mathbf{7}$ to 9 & $\mathbf{1 0 +}$ & Total \\
\hline 2003 & $14 \%$ & $13 \%$ & $22 \%$ & $26 \%$ & $14 \%$ \\
\hline 2004 & $14 \%$ & $13 \%$ & $25 \%$ & $32 \%$ & $15 \%$ \\
\hline 2005 & $13 \%$ & $13 \%$ & $29 \%$ & $36 \%$ & $15 \%$ \\
\hline 2006 & $13 \%$ & $13 \%$ & $27 \%$ & $26 \%$ & $14 \%$ \\
\hline
\end{tabular}

Household size in 1994 did not included in the analysis due to unavailable data. The greater the household size the more likely the household will be considered relatively poor. There is almost a doubling in percent age for households that have at least 10 members against the probability for a family of between 7 and 9 members. There is also a doubling of probability from the (1-3) and (4-6) age categories to the (7-9) age categories of the probability of being considered relatively poor. The likelihood is lowest among households with 4 to 6 members; but this is only marginally lower than those households that have between 1 and 3 members. The mean for relative poverty against household size remained constant over the period measured.

Table 5. Annual income, educational degree and relative poverty rates

\begin{tabular}{|l|c|c|c|c|c|}
\hline Education & $\mathbf{1 9 9 4}$ & $\mathbf{2 0 0 3}$ & $\mathbf{2 0 0 4}$ & $\mathbf{2 0 0 5}$ & $\mathbf{2 0 0 6}$ \\
\hline below primary & $38 \%$ & $39 \%$ & $43 \%$ & $45 \%$ & $41 \%$ \\
\hline elementary & $17 \%$ & $16 \%$ & $16 \%$ & $14 \%$ & $15 \%$ \\
\hline secondary & $8 \%$ & $7 \%$ & $7 \%$ & $9 \%$ & $8 \%$ \\
\hline high school & $4 \%$ & $5 \%$ & $4 \%$ & $4 \%$ & $4 \%$ \\
\hline university & $2 \%$ & $1 \%$ & $1 \%$ & $1 \%$ & $1 \%$ \\
\hline graduate & $0 \%$ & $0 \%$ & $0 \%$ & $0 \%$ & $0 \%$ \\
\hline total & $18 \%$ & $14 \%$ & $15 \%$ & $15 \%$ & $14 \%$ \\
\hline
\end{tabular}

As it can be seen in Table 5, the poverty ratio is very strongly tied to educational level. Those who were below primary school were 40 times more likely to be in relative poverty category than those who were collegiate graduate. Approximately $95 \%$ of the instances of relative poverty were among households whose 
heads had only secondary level of education or lower for all five periods. Therefore, the educational status of the respondents of these surveys is by the far the most dependent variable in determining poverty profile.

Table 6. Annual income, occupational status and relative poverty rates

\begin{tabular}{|l|c|c|c|c|c|}
\hline \multicolumn{1}{|c|}{ Occupational Status } & $\mathbf{1 9 9 4}$ & $\mathbf{2 0 0 3}$ & $\mathbf{2 0 0 4}$ & $\mathbf{2 0 0 5}$ & $\mathbf{2 0 0 6}$ \\
\hline Administrators & $2 \%$ & $2 \%$ & $3 \%$ & $2 \%$ & $2 \%$ \\
\hline professionals & $4 \%$ & $0,50 \%$ & $0.9 \%$ & $1,40 \%$ & $0,10 \%$ \\
\hline Technicians & $5 \%$ & $0,20 \%$ & $0,20 \%$ & 0,1 & $0,10 \%$ \\
\hline office clerks and costumer service & $4 \%$ & $2 \%$ & $1 \%$ & $0 \%$ & $1 \%$ \\
\hline service, shop and market sales & $15 \%$ & $13 \%$ & $10 \%$ & $9 \%$ & $8 \%$ \\
\hline Agriculture & $34 \%$ & $21 \%$ & $22 \%$ & $19 \%$ & $23 \%$ \\
\hline craft and related trade workers & $16 \%$ & $11 \%$ & $13 \%$ & $11 \%$ & $13 \%$ \\
\hline machine operators & $16 \%$ & $7 \%$ & $5 \%$ & $4 \%$ & $4 \%$ \\
\hline unskilled elementary occupations & $17 \%$ & $28 \%$ & $29 \%$ & $25 \%$ & $25 \%$ \\
\hline Total & $17 \%$ & $11 \%$ & $12 \%$ & $11 \%$ & $11 \%$ \\
\hline
\end{tabular}

In Table 6, the highest percentage of poverty were among people working in agriculture $(34 \%)$ in 1994 , but it switched to unskilled or elementary occupations in 2003, showing a $28 \%$ poverty rate among unskilled occupants. Relative poverty was relevant among elementary or unskilled, agriculture, craft and services occupants respectively.

Table 7. Annual income, employment status and relative poverty rates

\begin{tabular}{|c|c|c|c|c|c|}
\hline Years & Regular employee & Casual employee & Employer & Self employed & Total \\
\hline 1994 & $9 \%$ & $33 \%$ & $0 \%$ & $19 \%$ & $17 \%$ \\
\hline 2003 & $3 \%$ & $29 \%$ & $1 \%$ & $16 \%$ & $10 \%$ \\
\hline 2004 & $2 \%$ & $32 \%$ & $2 \%$ & $17 \%$ & $10 \%$ \\
\hline 2005 & $3 \%$ & $27 \%$ & $0.7 \%$ & $17 \%$ & $10 \%$ \\
\hline 2006 & $2 \%$ & $25 \%$ & $3 \%$ & $17 \%$ & $9 \%$ \\
\hline
\end{tabular}

In terms of employment status Table 7 displays that overall poverty rate dropped $17 \%$ to $10 \%$ from 1994 to 2006 . Relative poverty rate varied in 2000 s $25 \%$ to $29 \%$ among casual workers, and $16 \%$ to $19 \%$ among self-employed category.

In summary, the percentage of relative poverty was double among female and rural places as compared to male and urban centers. It was lowest and stable between the age groups of 40 to 60 . In all six years, $95 \%$ of the respondents that fell under the relative poverty line had an educational level of primary school and below. The other noticeable change between 1994 and 2003 was between agricultural and unskilled elementary occupants. In 1994 the relative poverty rate for agricultural workers were 34\% decreased to $21 \%$ in 2003 , in contrast to unskilled occupants, where the rate of poverty increased from $17 \%$ in 1994 to $27 \%$ in 2003 . In following pages, relative poverty was decomposed in terms of household heads' monthly income through 2003 and 2006. We did not include 1994 survey due to incompatibility of 1994 monthly income category with 2003 through 2006. 1994 and 2003 data were very similar and three times bigger than 2004, 2005 and 2006 data. Therefore, in cross-tabs analysis 3\% to 4\% more poverty rate can be expected 2004, 2005 and 2006 data.

Table 8. Monthly income and rural-urban locations and relative poverty rates

\begin{tabular}{|c|c|c|c|}
\hline Years & Rural & Urban & Total \\
\hline 2003 & $20 \%$ & $10 \%$ & $13 \%$ \\
\hline 2004 & $24 \%$ & $10 \%$ & $14 \%$ \\
\hline 2005 & $25 \%$ & $11 \%$ & $15 \%$ \\
\hline 2006 & $25 \%$ & $10 \%$ & $14 \%$ \\
\hline
\end{tabular}

The relative poverty rates for rural heads of household varied $5 \%$ over the period. The rate of relative poverty remained unchanged for urban residency over the period. The mean over the period as well remained approximately the same. The ratio of rural to urban relative poverty rates was approximately double for all years considered. 
Table 9. Monthly income, gender and relative poverty

\begin{tabular}{|c|c|c|c|}
\hline Years & Male & Female & Total \\
\hline 2003 & $12 \%$ & $25 \%$ & $13 \%$ \\
\hline 2004 & $13 \%$ & $26 \%$ & $14 \%$ \\
\hline 2005 & $14 \%$ & $27 \%$ & $15 \%$ \\
\hline 2006 & $13 \%$ & $26 \%$ & $14 \%$ \\
\hline
\end{tabular}

There is at least a $10 \%$ difference between matriarchal and patriarchal households with matriarchal respondents being almost twice as likely to be considered relatively poor. This may be related to temporary work or job volatility among female. With regards to monthly income the average rate was about $13 \%$ among male respondents and $25 \%$ among female respondents with regards to monthly income.

Table 10. Monthly income, age and relative poverty

\begin{tabular}{|c|c|c|c|c|c|c|}
\hline & 29\&below & $\mathbf{3 0}$ to39 & $\mathbf{4 0}$ to49 & $\mathbf{5 0}$ to59 & $\mathbf{6 0 +}$ & Total \\
\hline 2003 & $13 \%$ & $11 \%$ & $11 \%$ & $12 \%$ & $20 \%$ & $13 \%$ \\
\hline 2004 & $14 \%$ & $10 \%$ & $12 \%$ & $13 \%$ & $23 \%$ & $14 \%$ \\
\hline 2005 & $11 \%$ & $11 \%$ & $13 \%$ & $15 \%$ & $23 \%$ & $15 \%$ \\
\hline
\end{tabular}

Due to the nature in which the data was collected the results are unavailable for 2006. The results indicate that the incidence of relative poverty was relatively high among household heads were above the age of 60. The mean for the period remained unchanged, with no significant increase or decrease for other age categories.

Table 11. Monthly income, household size and relative poverty

\begin{tabular}{|c|c|c|c|c|c|}
\hline Years & $\mathbf{1}$ to 3 & $\mathbf{4}$ to 6 & $\mathbf{7}$ to 9 & $\mathbf{1 0 +}$ & Total \\
\hline 2003 & $13 \%$ & $12 \%$ & $21 \%$ & $24 \%$ & $13 \%$ \\
\hline 2004 & $13 \%$ & $12 \%$ & $24 \%$ & $33 \%$ & $14 \%$ \\
\hline 2005 & $13 \%$ & $13 \%$ & $27 \%$ & $32 \%$ & $15 \%$ \\
\hline 2006 & $12 \%$ & $11 \%$ & $23 \%$ & $25 \%$ & $13 \%$ \\
\hline
\end{tabular}

Poverty rate was almost same among 1-3 and 4-6 person households averaging 13\%. The likelihood of a household being considered relatively poor in the 7-9 group was almost twice the likelihood of the smaller familial categorizations. The probability as well increased in moving from the 7-9 brackets to the 10 and over category. Therefore, the more household size gets bigger the more poverty rates. There were only marginal differences between annual and monthly income in poverty incidences. About 1 to $2 \%$ differences between monthly and yearly income with this finding being only marginally significant if at all. This may lead to the assumption that monthly income is more strongly volatile than annual income.

Table 12. Monthly income, educational degree and relative poverty rates

\begin{tabular}{|l|c|c|c|c|}
\hline \multicolumn{1}{|c|}{ Education } & $\mathbf{2 0 0 3}$ & $\mathbf{2 0 0 4}$ & $\mathbf{2 0 0 5}$ & $\mathbf{2 0 0 6}$ \\
\hline below primary & $37 \%$ & $40 \%$ & $43 \%$ & $47 \%$ \\
\hline Elementary & $14 \%$ & $15 \%$ & $14 \%$ & $13 \%$ \\
\hline Secondary & $6 \%$ & $6 \%$ & $8 \%$ & $7 \%$ \\
\hline high school & $4 \%$ & $3 \%$ & $4 \%$ & $4 \%$ \\
\hline University & $1 \%$ & $1 \%$ & $0.2 \%$ & $1 \%$ \\
\hline Graduate & $0 \%$ & $0 \%$ & $0 \%$ & $0 \%$ \\
\hline Total & $13 \%$ & $14 \%$ & $15 \%$ & $13 \%$ \\
\hline
\end{tabular}

Again, we can see some minor differences between annual and monthly income related to education. Comparing annual and monthly income in terms of educational degree, we see two percent less poverty cases among them. Overwhelming, the majority of incidences of poverty belonged to the lowest two educational levels of completion, primary and secondary school, in compilation with literate and illiterate respondents constituting over $95 \%$ of the probability to be considered relatively poor. In this relationship, there is approximately a halving in the percentage of relative poverty when increasing educational level stepwise. 
Table 13. Monthly income, occupational status and relative poverty rates

\begin{tabular}{|l|c|c|c|c|}
\hline \multicolumn{1}{|c|}{ Occupations } & $\mathbf{2 0 0 3}$ & $\mathbf{2 0 0 4}$ & $\mathbf{2 0 0 5}$ & $\mathbf{2 0 0 6}$ \\
\hline Administrators & $2 \%$ & $1 \%$ & $3 \%$ & $2 \%$ \\
\hline professionals & $0.5 \%$ & $0.3 \%$ & $1 \%$ & $1 \%$ \\
\hline Technicians & $1 \%$ & $0 \%$ & $3 \%$ & $0.7 \%$ \\
\hline office clerks and costumer & $1 \%$ & $0.4 \%$ & $0.4 \%$ & $0.4 \%$ \\
\hline service, shop and market sales & $6 \%$ & $6 \%$ & $6 \%$ & $6 \%$ \\
\hline Agriculture & $20 \%$ & $25 \%$ & $23 \%$ & $24 \%$ \\
\hline craft and related trade workers & $8 \%$ & $9 \%$ & $8 \%$ & $8 \%$ \\
\hline machine operators & $3 \%$ & $3 \%$ & $3 \%$ & $3 \%$ \\
\hline unskilled occupations & $21 \%$ & $21 \%$ & $17 \%$ & $16 \%$ \\
\hline Total & $10 \%$ & $10 \%$ & $10 \%$ & $9 \%$ \\
\hline
\end{tabular}

When annual and monthly incomes are compared for the agricultural category, there were $3 \%$ to $4 \%$ more poverty cases in terms of monthly income. This is expected to be strongly tied to the fact that the work is seasonal in nature.

Table 14. Monthly income, employment status and relative poverty rates

\begin{tabular}{|c|c|c|c|c|c|}
\hline & $\begin{array}{c}\text { regular } \\
\text { employee }\end{array}$ & Casual Employee & employer & self employed & total \\
\hline 2003 & $3 \%$ & $29 \%$ & $1 \%$ & $16 \%$ & $10 \%$ \\
\hline 2004 & $2 \%$ & $32 \%$ & $2 \%$ & $17 \%$ & $10 \%$ \\
\hline 2005 & $3 \%$ & $27 \%$ & $0.7 \%$ & $17 \%$ & $10 \%$ \\
\hline 2006 & $2 \%$ & $25 \%$ & $3 \%$ & $17 \%$ & $9 \%$ \\
\hline
\end{tabular}

Regular employees were more than $3 \%$ more unlikely to be considered relatively poor between 2003 and 2006.The likelihood for respondent employers to be considered relatively poor doubled; however, the significance is at best marginal. The mean remained consistent for employed persons, which is $5 \%$ less than the mean from other tables indicating that unemployed respondents composed about $5 \%$ of the category of persons considered relatively poor.

To summarize all of the results discussed in cross-tabs tables, logistic regressions were run to measure the relative influence of each of the socio-economic variables. In table 15, 1994 and 2003 data were compared. As mentioned in previous sections data analyzed across all years were not uniform with regards to sample size and income measurements. It was more appropriate to run logit separately between 1994 to 2003 and 2003 to 2006. While employment status included in 2003 and 2006, it was not in 1994. Therefore; in table 15, 1994 and 2003 data separately compared.

Table 15. Logit results and relative poverty according to 1994-2003 annual income

\begin{tabular}{|l|l|l|l|}
\hline & \multicolumn{1}{|c|}{$\mathbf{B}$} & \multicolumn{1}{|c|}{ S.E. } & \multicolumn{1}{c|}{$\operatorname{Exp}(\mathbf{B})$} \\
\hline year (2003) &,$- 390^{* * * *}$ &, 028 &, 677 \\
\hline Illiterate & $1,688^{* * * * *}$ &, 060 & 5,409 \\
\hline Literate/no diploma & $1,203^{* * * * *}$ &, 065 & 3,331 \\
\hline elementary school &, $656^{* * * * *}$ &, 053 & 1,926 \\
\hline high school &,$- 696 * * * *$ &, 076 &, 499 \\
\hline College & $-2,600^{* * * *}$ &, 236 &, 074 \\
\hline Graduate & $-18,493 * * * *$ & $2,758 \mathrm{E} 3$ &, 000 \\
\hline Administrators & $-1,048^{* * * *}$ &, 127 &, 350 \\
\hline Technicians &,$- 682^{* * * *}$ &, 095 &, 506 \\
\hline Service &, $086^{*}$ &, 041 & 1,090 \\
\hline Agriculture &, $322^{* * * *}$ &, 045 & 1,380 \\
\hline machine operators &,$- 257 * * * *$ &, 064 &, 773 \\
\hline unskilled occupations &, $447 * * * *$ &, 042 & 1,564 \\
\hline self-employed &,$- 228 * * * *$ &, 040 &, 796 \\
\hline Employers & $-1,773 * * * *$ &, 163 &, 170 \\
\hline
\end{tabular}




\begin{tabular}{|l|l|l|l|}
\hline Female &, $379 * * * *$ &, 040 & 1,461 \\
\hline Urban &,$- 221 * * * *$ &, 027 &, 802 \\
\hline Constant & $-2,341$ &, 087 &, 096 \\
\hline -2log likelihood & 42318,803 & & \\
\hline chi-square & $5593,207 * * * *$ & & \\
\hline Nagelkerke R square & 0,161 & & \\
\hline overall percentage & 87 & & \\
\hline degree of freedom & 1 & & \\
\hline number of cases & 52,320 & \\
\hline
\end{tabular}

Note: $* \mathrm{p}, * * \mathrm{p}, * * * \mathrm{p}$, and $* * * * \mathrm{p}$ indicate significance at the level of $* \mathrm{p}<0.05 ; * * \mathrm{p}<0.01, * * * \mathrm{p}<0.001, * * * * \mathrm{p}<0.0001$

In table 15, dependent variable was annual income. 1994, secondary school, professional occupation, male and rural were control variables. As the table 15 indicate that respondents in 2003 were statistically less likely to be in relative poverty category in which poverty significantly dropped within 9 years period. In 1994 and 2003, those who were below secondary school, female, agricultural workers together with unskilled occupants had significant positive impact on relative poverty incidence. In table 16, we further compared variation in relative poverty between 2003 and 2006 data. Annual income again was dependent variable. Secondary education, professional occupations, regular employee male and year of 2003 were control variables.

Table 16. Yearly Income logistic regression

\begin{tabular}{|l|l|l|l|}
\hline & \multicolumn{1}{|c|}{$\mathbf{B}$} & \multicolumn{1}{|c|}{ S.E. } & \multicolumn{1}{c|}{$\mathbf{E x p ( B )}$} \\
\hline y2004 & $-0,008$ & 0,04 & 0,992 \\
\hline y2005 & 0,003 & 0,039 & 1,003 \\
\hline y2006 & $-0,048$ & 0,039 & 0,953 \\
\hline below elementary & $1,573^{* * * *}$ & 0,06 & 4,823 \\
\hline Elementary &, $575^{* * * *}$ & 0,056 & 1,777 \\
\hline High school &,$- 395^{* * * *}$ & 0,074 & 0,673 \\
\hline College & $-2,278^{* * * *}$ & 0,192 & 0,102 \\
\hline Graduate & $-18,905$ & $2,47 \mathrm{E}+03$ & 0 \\
\hline Administrators & $-1,613^{* * * *}$ & 0,112 & 0,199 \\
\hline Technicians & $-1,581^{* * * *}$ & 0,177 & 0,206 \\
\hline office clerks and costumer service & $-2,086^{* * * *}$ & 0,234 & 0,124 \\
\hline service, shop and market sales &,$- 655^{* * * *}$ & 0,069 & 0,519 \\
\hline Agriculture &,$- 485^{* * * *}$ & 0,077 & 0,616 \\
\hline craft and related trade workers & $-1,009^{* * * *}$ & 0,06 & 0,365 \\
\hline machine operators & $-1,216^{* * * *}$ & 0,077 & 0,296 \\
\hline unskilled elementary occupations &,$- 300^{* * * *}$ & 0,056 & 0,741 \\
\hline Employer &,$- 994^{* * * *}$ & 0,165 & 0,37 \\
\hline casual employee & $1,749^{* * * *}$ & 0,057 & 5,749 \\
\hline self employer &, $284 * * * *$ & 0,068 & 1,328 \\
\hline Female &, $619^{* * * *}$ & 0,039 & 1,857 \\
\hline Urban &,$- 162^{* * * *}$ & 0,031 & 0,85 \\
\hline Constant & $-2,034^{* * * *}$ & 0,061 & 0,131 \\
\hline -2log likelihood & 34900,790 & & \\
\hline chi-square & $7801,858^{* * * *}$ & & \\
\hline Nagelkerke R square & 0,249 & & \\
\hline overall percentage & 86 & & \\
\hline degree of freedom & 21 & & \\
\hline number of cases & 51,616 & & \\
\hline
\end{tabular}

Note: $* \mathrm{p}, * * \mathrm{p}, * * * \mathrm{p}$, and $* * * * \mathrm{p}$ indicate significance at the level of *p $<0.05 ; * *$ $\mathrm{p}<0.01, * * * \mathrm{p}<0.001, * * * * \mathrm{p}<0.0001$

The results displayed that there was no statistically significant differences between 2003, 2004, 2005 and 2006. Relative poverty in these years again positively associated with below secondary school level, 
casual or seasonal workers, self-employed people, female and rural location. After employment status were taken into account positive effect of service, agriculture and unskilled occupations wiped out and only casual or seasonal workers, and self employed stayed positively significant on the probability of relative poverty.

Table 17. Logistic Regression and Monthly Income

\begin{tabular}{|c|c|c|c|}
\hline & $\mathbf{B}$ & S.E. & $\operatorname{Exp}(B)$ \\
\hline y2004 & 056 & ,040 & 1,058 \\
\hline y2005 &, $126 * * *$ & ,039 & 1,134 \\
\hline y2006 &,- 012 & ,040 & ,988 \\
\hline below elementary & $1,532 * * * *$ & ,063 & 4,630 \\
\hline Elementary &, $550 * * * *$ & ,059 & 1,733 \\
\hline high school & $-0,376 * * * *$ & ,078 & ,687 \\
\hline College & $-2,307 * * * *$ &, 190 &, 100 \\
\hline Graduate & $-18,990$ & $2,457 \mathrm{E} 3$ & ,000 \\
\hline Administrators & $-2,445 * * * *$ &, 126 & ,087 \\
\hline Technicians & $-2,458 * * * *$ & ,236 & 086 \\
\hline $\begin{array}{l}\text { office clerks and costumer } \\
\text { service }\end{array}$ & $-2,489 * * * *$ & ,271 & ,083 \\
\hline $\begin{array}{l}\text { service, shop and market } \\
\text { sales }\end{array}$ & $-1,234 * * * *$ & ,081 & ,291 \\
\hline Agriculture &,$- 907 * * * *$ & ,083 & ,404 \\
\hline $\begin{array}{l}\text { craft and related trade } \\
\text { workers }\end{array}$ & $-1,673 * * * *$ & ,071 &, 188 \\
\hline machine operators & $-2,048 * * * *$ & ,098 &, 129 \\
\hline $\begin{array}{l}\text { unskilled elementary } \\
\text { occupations }\end{array}$ &,$- 947 * * * *$ & ,066 & ,388 \\
\hline Employer &,$- 443 * * * *$ & , 169 & ,649 \\
\hline casual employee & $1,721 * * * *$ & 067 & 5,591 \\
\hline self employed &, $869 * * * *$ &, 074 & 2,383 \\
\hline Female &, $453 * * * *$ & 039 & 1,574 \\
\hline Urban &,$- 150 * * * *$ & ,031 & ,861 \\
\hline Constant & $-1,994 * * * *$ & ,064 & , 136 \\
\hline -2log likelihood & 32959,028 & & \\
\hline chi-square & 7603,814 & & \\
\hline Nagelkerke R square & 0,252 & & \\
\hline overall percentage & 87 & & \\
\hline degree of freedom & 21 & & \\
\hline number of cases & 51,616 & & \\
\hline
\end{tabular}

Note: $* \mathrm{p}, * * \mathrm{p}, * * * \mathrm{p}$, and $* * * * \mathrm{p}$ indicate significance at the level of $* \mathrm{p}<0.05 ; * *$

$$
\mathrm{p}<0.01, * * * \mathrm{p}<0.001, * * * * \mathrm{p}<0.0001
$$

In table 17, in terms of monthly income, below secondary school, casual workers, self-employee, female and rural had significant influence on relative poverty as well. In summary, in all three tables, below secondary school level of education, female and rural had strong positive impact on relative poverty at the probability of 0.0001 levels. Secondly, self employed people in 1994 and 2003 had significant negative impact on poverty, however, when adding employment status to logistic equation in table 16, positive significant impact of agriculture and unskilled occupation disappeared, and only wager and self-employment remained significant impact on poverty. In all logistic equations relative poverty strongly associated with below secondary school educational level, casual workers and self employment category. Therefore, it is possible to conclude that those who had below secondary school education, worked as seasonal or as wager and self employed were more likely to fall under relative poverty category. As it can be seen from tables, the rest of the demographic and socio-economic variables had strong significant negative impact on relative poverty. Relative poverty significantly dropped in through 2006 after 1994 controlled. 


\section{Conclusion}

In this study, the level of poverty and poverty profiles based on annual and monthly income are analyzed in Turkey during the period spanning 1994-2006. Poverty was defined as level of income set below at 50 percent of the median annual and monthly income. Overall, cross-tabs indicated that there were 5\% drop rate in relative poverty incidences between 1994 and 2006. Poverty rate were double for female and rural locations in comparison to male and urban places. Poverty was concentrated at the elementary school and below level of education. In the second set, we analyzed relative poverty rate with regards to monthly disposable income between 2003 and 2006. Results showed there were almost no differences among 2003, 2004 and 2005 but significantly decreased in 2006 when monthly income criteria was used as dependent variables. There was also not a big variation between annual and monthly income criteria between the years 2003, 2004, 2005 and 2006.

Finally, we tested the relative effect of each socio-economic and demographic variable on relative poverty. Logit analysis indicated that no matter which income category was used the variable of primary or elementary school and below household heads, wage earner or casual workers, and to some extent selfemployed respondents and rural had significant positive impact on relative poverty incidence in the country in 1994, 2003, 2004, 2005 and 2006. The rest of the variables had a significantly negative impact on the incidence of relative poverty.

In conclusion, the results indicate that a low educational level and employment status are both strongly tied to the level of incidence of relative poverty. An increase in the level of education strongly decreases the likelihood for relative poverty rates, for both annual and monthly income criteria, by almost halving the level for each stepwise increase. Illiterate respondents in this analysis represent $7 \%$ percent of the population but account for $90 \%$ of the households subsisting in relative poverty. This shows that the importance of education to rescue from poverty. The results showed that relative poverty was closely correlated with at the primary school and below level of education, casual or seasonal employment status and rural places in all years considered.

\section{References}

1. Barusch, A.S.(2002). Foundations of social Policy. Illinois: F.E. Peacock Publishers Inc.

2. Bugra, A.(2008). Kapitalizm, yoksulluk ve turkiye'de sosyal politika. İstanbul: Iletişim Yayınları.

3. Bugra, A.,\& Keyder, C. (2003), New Poverty and the Changing Welfare Regime of Turkey, Ankara: UNDP.

4. Bugra, A. Keyder, C. (2005). Poverty and social policy in Turkey. Framework Paper. Retrieved from http://www.spf.boun.edu.tr/docs/WP-Bugra-Keyder.pdf

5. Bugra, A.,\& Sinmazdemir, N. T. (2005). Yoksullukla mucadelede insani ve etkin bir yontem: nakit gelir destegi. Bogazici Universitesi Sosyal Politika Formu, Arastirma Projesi. Istanbul: Bogaziçi Universitesi Yayını.

6. Dagdemir, O. (1999). Turkiye ekonomisinde yoksulluk sorunu ve analizi, 1987-1994. H.U. İIBF Dergisi, Sayı 1.

7. Devlet İstatistik Enstitusu (DIE). (1994). hanehalki tuketim harcamalari yontem ve kavramlari. Ankara: T.C. Basbakanlık Devlet Istatistik Enstitusu.

8. Devlet İstatistik Enstitusu (DİE). (2004). DIE haber bulteni, 2002 Yoksulluk Çalışması Sonuçları, Ankara: DİE.

9. Dikmen, A. (2002). Kentlesme, Goc ve Yoksulluk. Istanbul: Seckin Yayıncılık.

10. Dumanli, R. (1996). Yoksulluk ve turkiye'deki boyutları DPT Uzmanlık Tezi, Yayin No: DPT: 2449, Ankara: DPT.

11. Erdogan, G. (1998). Turkiye'de yoksulluk: boyutu ve profili, Ankara:DIE.

12. Erdogan, N. (2003). Yoksulluk halleri. İstanbul: De:ki Yayinlari.

13. Es, M.,\& Guloglu, T. (2004). Bilgi toplumuna gecişte kentlileşme ve kentsel yoksulluk:istanbul ornegi. Bilgi Sosyal Bilimler Dergisi. 1, 79-93.

14. European Commission, Eurostat. 2012. Retrieved from http://epp.eurostat.ec.europa.

15. Guloglu, T., \& Aydin, K. (2011). The socio-economic analysis of relativepoverty in Turkey. Changes In Social And Business Environment. Proceedings of the 4th Internatıonal Conference (pp.70-74). Panevežys: Kaunas University of Technology.

16. Guloglu, T.,\& Yumusak, I. G. (2008). The global retirement crisis in knowledge society. The Journal of Knowledge Economy \& Knowledge Management, 3, 111-125.

17. Guloglu, T.,\&Guder, G. (2007). Poverty and income inequality in Turkey: toward acession to european union. K. Dagci,\& G.T. Dagci (Eds.), Rethinking Turkey EU Relations (pp.175-197). Munster: MV-Wissenschaft. 
18. Gursel, Seyfettin, (2000), Turkiye'de bireysel gelir dagilimi ve yoksulluk, avrupa birligi ile karşilaştirma. Istanbul:TUSIAD.

19. Glynn, J., Hohm, C.F., \& Stewart, E.W. (1996). Global Social Problems.NY: HarperCollins Publishers Inc.

20. Haan, A. (2007). Reclaiming social policy. NY: Palgrave Macmillan.

21. Liddiard, M. (2007). Social need and patterns of inequality. Baldock, J., Mannning, N.,\& Viclerstaff, S. (Eds), Social Policy, Thid Edition, NY: Oxford University Press.

22. Neubeck, K.J.,\& Mary Alice Neubeck, M.A. (1997). Social problems. Fourth Edition. NY: MCGraw-Hill.

23. Oktik, N. (2008).Turkiye'de yoksulluk calismalari. Istanbul: Yakin Kitabevi.

24. Ozcan, Y.,\& Ozcan, K. (2003). Measuring poverty and inequality in Turkey, 2001. Topics in Middle Eastern and North African Economies, electronic journal, Volume 5, Middle East Economic Association and Loyola University. Chicago.

25. Sen, Amartya (1992). Inequality reexamined: New York: Russell Sage Foundation.

26. Sen, A. (1999). Development as freedom. New York: Alfred A. Knopf.

27. Senses, F. (2002) "Kuresellesmenin oteki yuzu yoksulluk. Istanbul: Iletisim Yayınlari.

28. Saunders, P. (1998). Towards a better poverty measure. In Focus, 2.

29. Turkish Statistical Institute (TUIK). (2003). Household budget and income distribution survey. Ankara: Turkish Statistical Institute Publishing.

30. Turkish Statistical Institute (TUIK). 2004, 2005, and 2006. Household consumption expenditure. Ankara: Turkish Statistical Institute Publishing

31. World Bank. (2000a). Turkey: economic reforms, living standards and social welfare study. Washington: World Bank Poverty Reduction and Economic Management Unit.

32. World Bank (2000b). World development report, 2000-2001. Attacking Poverty, Washington: World Bank.

33. World Bank. (2003). Turkey: poverty and coping after crises. Washington: World Bank Human Development Unit, Europe and Central Asia Region.

34. United Nations. (2009) Human Development Report. (2009). Retrieved from http://hdrstats.undp.org/indicators/28.html

35. United Nations. (2012) Human Development Report. (2011). Retrieved from http://hdrstats.undp.org/indicators/28.html

36. Yemtsov, R. (2001). Living standards and economic vulnerability in Turkey between 1987 and 1994. Washington: World Bank.

37. Yardımc1, Y., Alici, S., Uygur, S.,\& Ekni, S. (2003), Turkiye'de Kirsal Kesimde Hanehalklarinin Yoksulluk Profili. Ankara: DIE.

38. Yereli, B. B.,\& N. Basaran, A. (2006). "Self employment and relative poverty in Turkey. Paper Prepared for the $29^{\text {th }}$ General Conference of the International Association for Research in Income and Wealth. Finland. 